\title{
PREGNANCY; \\ THROMBOEMBOLIC COMPLICATIONS
}

\footnotetext{
1. M. Phil

Al-Noor Specialist Hospital Makah, K $S A$.

2. M. Phil

Department of Hematology and Immunology,

Um-Al-Qura University, Makah, KS A.

Correspondence Address: Dr. Muhammad Aslam Ahsan M. Phil

Al-Noor Specialist Hospital Makah, K $\mathrm{SA}$

draslam64@hotmail.com mrcheema1957@gmail.com
}

Article received on: 30/05/2015

Accepted for publication: 13/02/02016

Received after proof reading: 10/03/2016

\section{INTRODUCTION}

Pregnancy is associated with many physiological, biological, and anatomic changes, however, most systems return to non-pregnant state between the time of delivery and post-partum. ${ }^{1}$ The post-partum period extends up to six weeks after delivery and has been arbitrarily divided in to, Immediate puerperium (first 24 hours after parturition), Early puerperium (extending up to first post-partum week), and Remote puerperium (extending up till the 6 -th week post-partum). ${ }^{2}$ The most striking maternal physiological changes occurring during pregnancy are associated with hematological system. Progressive activation of clotting system, enhanced platelet activation and changes in fibrinolysis during pregnancy and puerperium present a unique challenge to the pregnant lady and it is believed to be a hypercoagulable state. ${ }^{3,4,5}$ Blood flow, particularly in the veins of limbs and pelvis may be reduced by pressure from pregnant uterus and bed rest. The combined effect of hypercoagulable state and venous stasis is responsible for the great risk of thromboembolism during pregnancy. ${ }^{6}$ Venous thrombosis is the commonest complication during pregnancy and puerperium, and pulmonary embolism is now the single major cause of maternal death associated with pregnancy. ${ }^{7}$ The greatest clinical problem is to recognize deep vein thrombosis and pulmonary embolism which can be effectively prevented by prophylactic anticoagulation. ${ }^{8,9}$ Thus recognition of a hypercoagulable state has primary importance in treatment and prevention of thromboembolic phenomenon. ${ }^{10}$

The TAT-Complex (Thrombin-antithrombinComplex), Prothrombin fragment $1+2$ and plasma D-dimer have been considered the sensitive markers for determining the functional state of the coagulation system. Their elevated levels have been shown to be associated with hyper coagulation and an increased risk of venous thrombosis.

\section{Selection Criteria}

Sixty women were selected between the age group of 20-40 years.

A. Twenty age matched normal, non-pregnant, non-diabetic and without a history of blood transfusion were selected as the control.

B. Twenty women in post-partum period within 24 hours following normal vaginal delivery.

C. Twenty women with caesarean-section within 
24 hours of the operation.

\section{Exclusion Criteria}

Women with a history of diabetes, blood transfusion within 12 days or the women taking non-steroidal anti-inflammatory drugs were excluded from the study.

\section{Blood Sampling}

$3.6 \mathrm{ml}$ of blood with $0.4 \mathrm{ml}$ of tri-sodium citrate was collected in a test tube for the determination of; Fibrinogen level, FDP level and plasma D-dimer test.

\section{RESULTS}

Forty (40) patients were included in this study, twenty with normal delivery and twenty with caesarean-section.

Comparison of fibrinogen concentration in normal delivery group (Group B), Caesarean-section group (group C) and controls (group A).

\begin{tabular}{|c|c|c|}
\hline Group A & Group B & Group C \\
\hline $\mathrm{n}=20$ & $\mathrm{n}=20$ & $\mathrm{n}=20$ \\
\hline $332.5 \pm 42.9$ & $519.5 \pm 69.8^{\star *}$ & $540 \pm 75.6 * \star$ \\
\hline$(267---383)$ & $(446---653)$ & $(446---653)$ \\
& $\begin{array}{c}\text { Table-I. Fibrinogen Assay } \\
\star \star P<0.05 \text { significant }\end{array}$ \\
\hline
\end{tabular}

The results of fibrinogen assay in different study groups are shown in table-I. In the control group (group A), the fibrinogen level was $332.5 \pm 42.9$ $\mathrm{mg} / \mathrm{dl}$ with a range from $267 \mathrm{mg} / \mathrm{dl}$ to $383 \mathrm{mg} / \mathrm{dl}$.

In normal delivery group (group-B), the fibrinogen level was $519.5 \pm 69.8 \mathrm{mg} / \mathrm{dl}$ with a range from 446 $\mathrm{mg} / \mathrm{dl}$ to $653 \mathrm{mg} / \mathrm{dl}$. This value was statistically significant as compared to control group ( $P$ $<0.05)$.

In caesarean section group (group-C), the fibrinogen level was $540 \pm 75.6 \mathrm{mg} / \mathrm{dl}$ with a range from $446 \mathrm{mg} / \mathrm{dl}$ to $653 \mathrm{mg} / \mathrm{dl}$. This value was also statistically significantly high as compared to control group $(P<0.05)$.

Statistically the difference in normal delivery group (fibrinogen level $519.5+69.8 \mathrm{mg} / \mathrm{dl}$ ) and caesarean-section group (fibrinogen level $540 \pm 75.6 \mathrm{mg} / \mathrm{dl})$ was non-significant $(P>0.05)$.

\begin{tabular}{|c|c|c|}
\hline \multicolumn{3}{|c|}{$\begin{array}{l}\text { Comparison of fibrin/fibrinogen degradation products } \\
\text { ( } \mu \mathrm{g} / \mathrm{ml}) \text { in controls (Group A), normal delivery group } \\
\text { (group B) and Caesarean-section group (group C). }\end{array}$} \\
\hline Group A & Group B & Group C \\
\hline$n=20$ & $\mathrm{n}=20$ & $\mathrm{n}=20$ \\
\hline $20^{`}<5 \mu \mathrm{g} / \mathrm{ml}$ & $17<20 \mu \mathrm{g} / \mathrm{ml}(85 \%)$ & $\begin{array}{c}12<20 \mu \mathrm{g} / \mathrm{ml} \\
(60 \%)\end{array}$ \\
\hline$(100 \%)$ & $3>20 \mu \mathrm{g} / \mathrm{ml}(15 \%)$ & $\begin{array}{c}8>20 \mu \mathrm{g} / \mathrm{ml} \\
(40 \%)\end{array}$ \\
\hline \multicolumn{3}{|c|}{$\begin{array}{l}\text { Table-II. Fibrin/Fibrinogen Degradation Products } \\
\text { (FDPs) }\end{array}$} \\
\hline
\end{tabular}

The results of Fibrin/Fibrinogen Products (FDPs) are shown in table-II. The plasma FDP levels in the control subjects (group-A) were within normal limits $(<5 \mu \mathrm{g} / \mathrm{ml})$. In normal delivery group (group-B), the levels of FDP were more than normal limits $(>5 \mu \mathrm{g} / \mathrm{ml})$ in all 20 subjects $(100 \%)$ It was less than $20 \mu \mathrm{g} / \mathrm{ml}$ in 17 subjects (85\%) and more than $20 \mu \mathrm{g} / \mathrm{ml}$ in 3 subjects (15\%) in this group.

In caesarean-section group (group-C), the increased levels were found in all 20 subjects $(100 \%)$. On further dilutions, FDP levels were found less than $20 \mu \mathrm{g} / \mathrm{ml}$ in 12 subjects (60\%), while more than $20 \mu \mathrm{g} / \mathrm{ml}$ were observed in 8 subjects $(40 \%)$.

Comparison of plasma D-Dimer levels $(\mu \mathrm{g} / \mathrm{ml})$ in controls (Group A), normal delivery group (group B) and Caesarean-section group (group C).

\begin{tabular}{|c|c|c|}
\hline Group A & Group B & Group C \\
\hline $\mathrm{n}=20$ & $\mathrm{n}=20$ & $\mathrm{n}=20$ \\
\hline $20^{\circ}<0.5 \mathrm{~g} / \mathrm{ml}$ & $\begin{array}{c}17<1.0 \mu \mathrm{g} / \mathrm{ml} \\
(85 \%)\end{array}$ & $\begin{array}{c}12<1 \mu \mathrm{g} / \mathrm{ml} \\
(60 \%)\end{array}$ \\
\hline$(100 \%)$ & $3>\begin{array}{c}1.0 \mu \mathrm{g} / \mathrm{ml} \\
(15 \%)\end{array}$ & $\begin{array}{c}8>1 \mu \mathrm{g} / \mathrm{ml} \\
(40 \%)\end{array}$ \\
\hline
\end{tabular}

Table-III. Plasma D-Dimer Test

The results of D-dimer Test in different groups are shown in table-III. The plasma D-dimer levels in control subjects (group-A) were within normal limits $(<0.5 \mu \mathrm{g} / \mathrm{ml})$ in all 20 subjects $(100 \%)$. 
In normal delivery group (group B), the plasma D-Dimer levels were increased ( $>0.5 \mu \mathrm{g} / \mathrm{ml}$ )in all 20 subjects (1000\%). The raised levels were less than $1.0 \mu \mathrm{g} / \mathrm{ml}$ in 17 subjects ( $85 \%$ ), while more than $1.0 \mu \mathrm{g} / \mathrm{ml}$ were observed in 3 subjects $(15 \%$ ). In caesarean-section group (group-C), the plasma D-dimer levels were increased in all 20 subjects $(100 \%)$. The increased levels were less than $1.0 \mu \mathrm{g} / \mathrm{ml}$ in 12 subjects (60\%), while more than $1 \mu \mathrm{g} / \mathrm{ml}$ were observed in 8 subjects $(40 \%)$.

\section{DISCUSSION}

Deep vein thrombosis and pulmonary embolism are being considered the major cause of maternal death during pregnancy and puerperium. The great clinical problem is to recognize deep vein thrombosis (DVT) and pulmonary embolism $(P E)$. Immediate puerperium is the most dangerous period because highest number of thromboembolic complications occurs during this period $^{11}$. In the present study plasma fibrinogen concentration levels were significantly elevated in both study groups. When these increased levels were compared with non-pregnant controls, the difference was significant. This finding was in conformity with different studies. . $^{3,412}$

The mean values of FDPs were found high in both $\mathrm{B}$ and $\mathrm{C}$ groups when compared with normal group-A. This is in accordance with the observations published. . $^{5}$

The mean values of plasma D-dimer were found significantly high in both normal delivery (group B) and caesarean-section (group $C$ ) patients, when compared to group-A (non-pregnant subjects). A similar observation was made by studies. ${ }^{5,12}$

\section{CONCLUSION}

It is recommended that the coagulation status of each lady should be properly evaluated in immediate puerperium and anticoagulation and other measures be adopted to prevent thromboembolic complications.

Copyright(C) 13 Feb, 2016.

\section{REFERENCES}

1. Howie PW. The physiology of the puerperium and lactation. In Geoffrey chamberlain ed. Turnbull, s obstetrics. Lind ed. New York: Pearson professional limited, 1995; 115---131.

2. Novy MJ. The normal puerperium. In: Pernoll edt. Current obstetric and gynecological diagnosis and treatment, $7^{\text {th }} \mathrm{Ed}$ London. Appleton and Lange publishing1991; 237---68.

3. Gerbasi FR, Bottoms S, Farag A, Mammon E. Increased intravascular coagulation associated with pregnancy. Obstet gynaecol 1990; 75: 385---9.

4. Bremme $\mathrm{K}$, Ostlund $\mathrm{E}$, Almavist I,Heino men $\mathrm{K}$ and Blom Back $M$. Enhanced thrombin generation and fibrinolytic activity in normal pregnancy and puerperium. Obstetrics and Gynecology 1992; 80: 132$--37$.

5. Toglia MR, Weg JG. Venous thromboembolism during pregnancy. The New England Journal of Medicine, 1996; 335: 108---14.

6. Lams JD. Physiological changes in pregnancy. In: Lams JD, Zuspan FP, Quilligan ED, eds. Manual of obstetrics and gynecology. 11nd Ed, Philadelphia: Mosby company, 1990:31---37.

7. Kernoff PBA. Thrombosis and antithrombotic therapy. In: Hoff-brand AV, Lawis SM, eds. Postgraguate haematology, $3^{\text {rd }}$ Ed Oxford: Heinemann professional publishing : 1989; 672---95.

8. Collins R, Secrimgeour A, Yusuf S, Peto R. Reduction in fatal pulmonary embolism and venous thrombosis by perioperative administration of subcutaneous heparin. N Eng J Med 1988; 18:1162---73.

9. THRIFT. Throboembolic risk factors consensus group. Risk of and prophylaxis for venous thromboembolism in hospital patients. $\mathrm{Br}$ Med $\mathrm{J}$ 1992; 305:567---74.

10. Bowen KG, Vukelja SJ. Hypercoagulable states, their causes and management. Postgrad-Med 1992; 91: 117---8.

11. Howie PW. The coagulation and fibrinolytic system and their disorders in obstetrics and gynecology, in Whitfield ed. Dewhurst, textbook of obstetrics and gynecology for postgraduates. $5^{\text {th }}$ edition. London: Blackwell science Ltd, 1995; 510---25.

12. Koh SCL, Arulkumaran S, Biswas A and Ratnam SS. The influence of labour and placental separation on hemostasis in term pregnancy. Clin Appl thrombosis / Hemostasis 1998; 4(4): 262---7. 


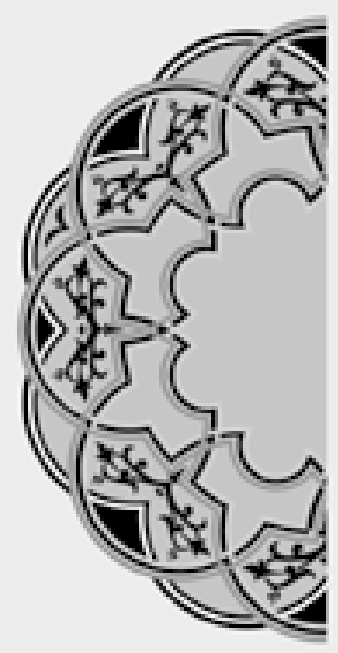

\title{
"Jobs fill our pocket. Adventures fill your soul."
}

\author{
Jaime Lyn
}

\section{AUTHORSHIP AND CONTRIBUTION DECLARATION}

\begin{tabular}{|c|l|l|l|}
\hline Sr. \# & \multicolumn{1}{|l|}{ Author-s Full Name } & \multicolumn{1}{|c|}{ Contribution to the paper } & Author=s Signature \\
\hline 1 & Dr. M. Aslam Ahsan & Data Collection & \\
2 & Dr. M. Rafique Cheema & Statistical Analysis & Netateres \\
\hline
\end{tabular}

